\title{
PURIFICATION AND ANALYSIS OF ALKALI CYANIDES
}

\author{
By M. R. Thompson
}

ABSTRACT

This paper summarizes the results of other investigators on the laboratory preparation of alkali cyanides of high purity, and considers several volumetric methods which have been used for the analysis of the product. Particular attention is given to the titrations with mercuric chloride (Hannay), nickel sulphate (Lundell) and silver nitrate (Liebig-Denigès).

In the present work, potassium and sodium cyanides were synthesized from liquid hydrocyanic acid and the appropriate hydroxide or ethoxide in ethyl alcohol solution. No difficulty was found in thus producing potassium cyanide of high purity, but the sodium cyanide was always less pure. This difference was traced to the reactions and solubility relations for potassium and sodium salts in ethyl alcohol. Methyl alcohol was found to be suitable for recrystallizing cyanides in certain cases, as the alkali salts are more soluble in it.

When applied to the pure potassium cyanide, the silver nitrate (LiebigDenigès) method of analysis was found to be the most accurate.

\section{CONTENTS}

II. Experimental work

1. Methods of handling and

2. Methods of purifying alkali cyanides by recrystallization

3. Methods of synthesizing pure alkali cyanides from liquid hydrocyanic acid.

III. Discussion of results

IV. Conclusions

V. Acknowledgments

VI. Bibliography

\section{INTRODUCTION}

Alkali cyanide is an essential constituent of solutions used to electroplate with certain metals, including gold, silver, copper cadmium, zinc, and their alloys. The present commercial standard of purity is from 94 to 96 per cent for potassium cyanide and 96 to 98 per cent for sodium cyanide. "Chemically pure" material appears to be merely a selected grade of the above. The most common impurities are moisture, carbonate, cyanate, chloride, formate, and cyanamide.

More extensive knowledge is needed on the properties and control of the cyanide plating baths, and lately there has been a marked increase in research in this field. Although alkali cyanide of the above purity is quite adequate for commercial use, there are cases in research when small amounts of purer material are required. One example is the determination of the accuracy of analytical control methods. 
Credit for very early achievements in the purification of potassium cyanide from ethyl alcohol solution should undoubtedly be given to Rogers and Rogers $(1)^{1}$ and to Wiggers (2), although unfortunately no analyses of the products were published. Later investigators used various methods of purification or synthesis and reported analyses. Their methods and results are summarized in Table 1. It is evident from Table 1 that nonaqueous solvents have been preferred, in order to prevent hydrolysis and the decomposition of cyanide.

TABLE 1.-Results on the preparation of pure alkali cyanides

\begin{tabular}{|c|c|c|c|c|c|c|}
\hline No. & Date & Author & Product & Purity & Method of preparation & Method of analysis \\
\hline 1 & 1875 & Loughlin (6)... & $\mathrm{KCN}$ & $\begin{array}{c}\text { Per } \\
\text { cent } \\
99.2\end{array}$ & Crystallization from car- & Titration with $\mathrm{AgNO}_{3}$. \\
\hline 2 & $15 \$ 2$ & Josnnis (8) & $\mathrm{NaCl}$ & 99.7 & Gaseous HCN and alco- & Titration with $\mathrm{I}_{2}$ (5). \\
\hline 3 & 1917 & Bucher (19) & $\ldots d$ & 99.9 & Distillation at $1,000^{\circ} \mathrm{C} . .$. & Titration with $\mathrm{AgNO}_{3}$. \\
\hline 4 & 1923 & Ingol & & 99.8 & $\begin{array}{l}\text { Liquid } \mathrm{HCN} \text { and aqueous } \\
\mathrm{NaOH} \text {. }\end{array}$ & Do. \\
\hline 5 & 1926 & $\begin{array}{l}\text { Guernsey and } \\
\text { Sherman (29). }\end{array}$ & ....do. & 99.95 & $\begin{array}{l}\text { Liquid HCN and alcoholic } \\
\text { NaOH. }\end{array}$ & $\begin{array}{l}\text { Titration with } \mathrm{NiSO}_{4} \\
\text { (16). }\end{array}$ \\
\hline 6 & 1926 & $\begin{array}{r}\text { Hackspill and } \\
\text { Grandadam }(30)\end{array}$ & $\left\{\begin{array}{l}\mathrm{KCN} \\
\mathrm{NaCN}\end{array}\right.$ & $\begin{array}{l}100.0 \\
100.0\end{array}$ & Crystallization from liquid & Titration with $\mathrm{AgNO}_{3}$. \\
\hline 7 & 1927 & Strachan $1 . .$. & -.. do & 100.0 & Liquid HCN and alcoholic & Do. \\
\hline 8 & 1031 & Thompson? & $\left\{\begin{array}{l}\mathrm{KCN} \\
\mathrm{NaCN} \\
\ldots \text { do. }\end{array}\right.$ & $\begin{array}{l}99.85 \\
99.43 \\
99.13\end{array}$ & $\left\{\begin{array}{l}\text { Liquid HCN and alcoholic } \\
\text { hydroxide. NaCN re- } \\
\text { crystallized from alcohol. } \\
\text { Liquid HCN and alcoholic } \\
\text { Na (ethoxide). }\end{array}\right.$ & $\begin{array}{l}\text { Titration with } \mathrm{AgNO}_{3} \\
\text { from weight burette, } \\
\text { using NaOH and } \mathrm{KI} \\
\text { indicator. }\end{array}$ \\
\hline
\end{tabular}

1 Private communication from E. K. Strachan, Brown University, Providence, R. I.

This paper.

Investigators have usually preferred the method of analysis which is the basis of all exact work with cyanides, namely, titration with standard silver nitrate solution. This appears to have been first described by Glassford and Napier (3), in 1844, but the papers of Liebig (4) in 1851 and 1852 attracted more attention and the method has always been inseparably associated with his name. Very important improvements, consisting in the addition of potassium iodide and an alkali, were described by Denigès (10) and by Sharwood (11). The accuracy has been studied from the aspect of the effects of large amounts of impurities, by Clennell (13), Burt-Gerrans and Morrison (15), Dott (18) and Sanigar (33); by comparison with other analytical methods, by Lundell (16), Frary and Porter (17), and Morris (22); and with relation to solubility determinations, by Bassett and Corbet (26).

The accuracy of the Liebig titration of cyanide has been questioned by Clevenger and Hall (14), who found certain results to be apparently 16 per cent low; but made no extensive investigation of the discrepancy; and by Frary and Porter (17), who compared the results with those by the mercuric chloride titration of Hannay (7). Frary and Porter found that the Liebig method gave results about 3 per cent lower than the Hannay method, when applied to their sample of potassium cyanide. They also believed that Liebig himself

The Agures given ti parentheses here and throughout the text relate to the reference numbers in the Liblicraphy given at the end of this paper. 
doubted the accuracy of his method. A careful study of Liebig's text, however, leads to the conclusion that he referred to the disappointingly low purity of the product of his manufacturing process and not to any recognized error in the analytical procedire used for determining this purity.

The history of the preparation of "pure" cyanide shows many instances of difficulties in repeating previous work, which difficulties have led to the development of new or modified procedures. Reasons for this situation may include lack of knowledge of the exact technique required, use of different analytical methods, and the instability of cyanogen compounds.

\section{EXPERIMENTAL WORK}

The experimental work of this investigation included a study and comparison of $(a)$ methods of handling and analyzing samples of alkali cyanide, $(b)$ methods of purifying alkali cyanide by recrystallization from organic solvents, and $(c)$ methods of synthesizing pure alkali cyanide from liquid hydrocyanic acid. Commercial cyanide was used in exploratory experiments not reported here.

\section{METHODS OF HANDLING AND ANALYZING SAMPLES OF ALKALI CYANIDE}

Moisture or alcohol was removed by drying for two or three days in a desiccator over phosphorus pentoxide, applying a vacuum when necessary. A carbon dioxide absorbent, such as "ascarite" (sodium hydroxide on asbestos), was also kept in the desiccator. Drying in an electric oven at $100^{\circ}$ to $125^{\circ} \mathrm{C}$. for several hours also gave good results, provided that reasonable precautions were used to exclude carbon dioxide.

Carbonate was occasionally determined, by precipitating cold with barium chloride and titrating the barium carbonate obtained. Cyanide was ordinarily determined by the modified Liebig titration, adopting as standard conditions; $0.1 N$ silver nitrate, $10 \mathrm{ml}$ of "indicator" solution containing $0.05 \mathrm{~N}$ potassium iodide and $0.25 \mathrm{~N}$ sodium hydroxide, a final titration volume of about $100 \mathrm{ml}$, room temperature and vigorous stirring. The purer samples were dissolved in the $10 \mathrm{ml}$ of alkaline indicator before diluting, in order to decrease the possible loss of hydrocyanic acid. Volumetric burettes were used for work of ordinary accuracy ( 0.2 to 0.3 per cent) and weight burettes when higher accuracy (0.1 per cent) was required.

Comparison with other volumetric methods for cyanide was obtained in a few cases by using the nickel sulphate titration of Lundell (16) in which dimethylglyoxime is used as the indicator in the presence of a small amount of ammonia, or the mercuric chloride titration of Hannay (7). Results by the latter were always several per cent higher than by the silver nitrate titration. For example, an average purity of 103.4 per cent was obtained for the fairly pure potassium cyanide sample listed in Table 4. Similar results for less pure material were reported by Frary and Porter (17). In addition, it was found in the present work that the results varied according to the way the mercury solution was prepared and to the conditions used in the titration. 


\section{METHODS OF PURIFYING ALKALI CYANIDE BY RECRYSTALLIZA- TION FROM ORGANIC SOLVENTS}

Recrystallization processes are attractive because of their simplicity and the avoidance of using the dangerous hydrocyanic acid. Organic solvents prevent or decrease the hydrolysis of cyanide and volatilization of hydrocyanic acid, which occur in aqueous solution. A suitable solvent should preferably $(a)$ possess a considerable difference in solvent action on cyanide and impurities, $(b)$ show but slight tendency to combine with cyanide directly or through condensation products, and $(c)$ have either a marked temperature coefficient of solubility for cyanide, or else a conveniently low boiling point.

Attempts were made to use carbon disulphide as the solvent, according to the procedure of Loughlin (6), but without success. No appreciable amount of potassium cyanide, sodium cyanide, or the impurities contained in them, was dissolved at room temperature. Treatment of potassium cyanide with boiling carbon disulphide also gave negative results. Those of Loughlin are, therefore, difficult to explain.

Ethyl alcohol has been commonly used for dissolving cyanide, but methyl alcohol does not appear to have been considered. As few data were available on the solubility of cyanides and related salts in alcohols, some approximate determinations were made. These results and other published data are summarized in Table 2. Data on the solubility of cyanides in liquid ammonia have been given by Hackspill and Grandadam (30).

TABLE 2.-Approximate solubilities of cyanides and related salts in alcohols at about $25^{\circ} \mathrm{C}$.

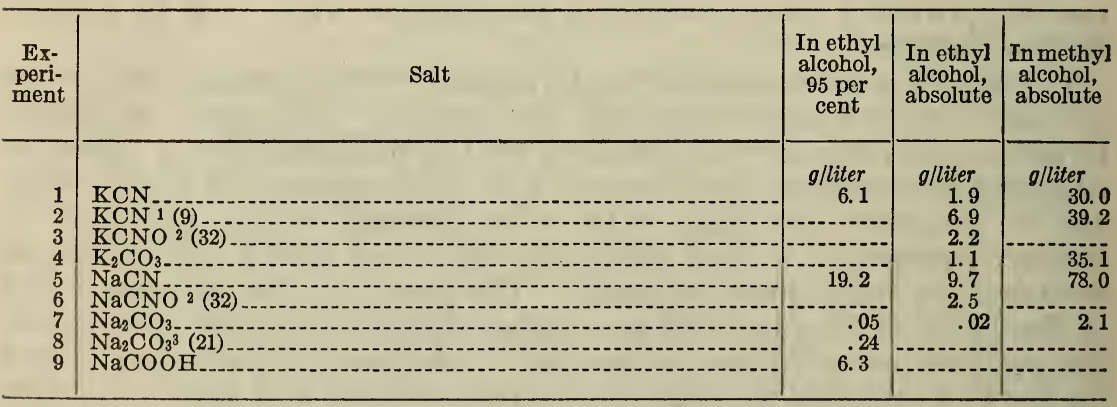

1 Determinations at $19.5^{\circ} \mathrm{C}$.

2 Interpolated by M. R. T. from results with about 98 per cent alcohol.

Determination at $30^{\circ} \mathrm{C}$.

Recrystallization experiments were made with both alcohols. Difficulties were encountered both in precipitating cyanide by "freezing out" and by boiling off the alcohol. The best results were obtained by slowly evaporating the alcohol in a stream of inert gas at a moderate temperature. Some typical data are reported in Table 3. 
TABLE 3.-Effect of recrystallization from alcohol or extraction with alcohol, upon the purity of alkali cyanides

[All analyses were done by the Jiebig titration, using $\mathrm{KI}-\mathrm{NaOH}$ indicator]

\begin{tabular}{|c|c|c|c|c|}
\hline $\begin{array}{l}\text { Ex- } \\
\text { peri- } \\
\text { ment }\end{array}$ & Sample & $\begin{array}{l}\text { Purity } \\
\text { before }\end{array}$ & $\begin{array}{l}\text { Purity } \\
\text { after }\end{array}$ & Remarks \\
\hline 1 & $\begin{array}{l}\mathrm{NaCN} \text { made from } \\
\text { HCN............. }\end{array}$ & $\left\{\begin{array}{r}\text { Per cent } \\
99.71 \\
98.52 \\
198.62\end{array}\right.$ & $\begin{array}{l}\text { Per cent } \\
\left\{\begin{array}{r}99.50 \\
99.35 \\
99.45 \\
199.43\end{array}\right.\end{array}$ & $\left\{\begin{array}{l}\text { Used absolute ethyl alcohol and evaporated at } 35^{\circ} \text { to } 40^{\circ} \\
\text { C. in a stream of nitrogen or hydrogen. Slight gain } \\
\text { in purity under preliminary conditions. Product } \\
\text { showed } 0.03 \text { per cent moisiure when drier at } 125^{\circ} \mathrm{C} \text {. } \\
\text { Analyzed with weight burette. }\end{array}\right.$ \\
\hline 2 & $\underset{\text { quality) }}{\mathrm{NaCN}}$ (reagent & 97.0 & 98.6 & $\begin{array}{l}\text { Used absolute methyl alcohol and evaporated at about } \\
20^{\circ} \mathrm{C} \text {. in a stream of hydrogen. Much coloring matter } \\
\text { present in solution at start and product graycr than } \\
\text { original matcrial. Very small scale work under pre- } \\
\text { liminary conditions. }\end{array}$ \\
\hline 3 & do & 97.2 & 97.3 & $\begin{array}{l}\text { Used boiling absolute methyl alcohol in an extraction } \\
\text { apparatus. No appreciable gain in purity. }\end{array}$ \\
\hline 4 & $\begin{array}{l}\text { KCN (reagent } \\
\text { quality). }\end{array}$ & 93.4 & 97.8 & $\begin{array}{l}\text { Used absolute methyl alcohol and evaporated at ahout } \\
35^{\circ} \mathrm{C} \text {. in a stream of hydrogen. Much coloring matter } \\
\text { present in solution at start, but product was less yellow } \\
\text { than original material. Distinct gain in purity, work- } \\
\text { ing on a very small scale under preliminary conditions. } \\
\text { Used boiling absolute methyl alcohol in an extraction } \\
\text { apparatus. Only a slight gain in purity. }\end{array}$ \\
\hline
\end{tabular}

1 Average.

\section{METHODS OF SYNTHESIZING PURE ALKALI CYANIDE FROM LIQUID HYDROCYANIC ACID}

Synthetic laboratury methodis depend upon the use of hydrocyanic acid, usually liquefied for ease in handling and measurement. The solvent for the alkali is usually absolute ethyl alcohol, in which the alkali is dissolved either as hydroxide or as ethoxide (28). Such methods are more rapid and efficient than recrystallization.

Experiments were made mainly by the procedure which has been recently described in detail by Guernsey and Sherman (29). When a filtered solution of the appropriate hydroxide ( $40 \mathrm{~g} /$ liter) is treated with a 10 per cent excess of liquid hydrocyanic acid, alkali cyanide is formed and most of it precipitated.

$$
\mathrm{NaOH}+\mathrm{HCN}=\mathrm{NaCN}+\mathrm{H}_{2} \mathrm{O}
$$

The unpublished method of E. K. Strachan ${ }^{2}$ was also tried in which a solution of sodium in alcohol $(40 \mathrm{~g} / \mathrm{l})$ is employed.

$$
\mathrm{C}_{2} \mathrm{H}_{5} \mathrm{ONa}+\mathrm{HCN}=\mathrm{NaCN}+\mathrm{C}_{2} \mathrm{H}_{5} \mathrm{OH}
$$

Hydrocyanic acid ${ }^{3}$ was generated either in the apparatus described by Wade and Panting (12), or that by Ziegler (24). 'The former gave some difficulty from tar formation, which is a reaction discussed by Pelton and Schwarz (20) and by Harker (23). No such trouble was found with the Ziegler apparatus when properly adjusted, but the larger volume of liquid present interfered somewhat with the evolution of the hydrocyanic acid.

In alcoholic solutions there is a tendency toward the formation of brown "aldehyde resins," which may contaminate the product. The preliminary removal of traces of aldehyde by an appropriate method (27) did not always solve the problem. The effect is greater for sodium hydroxide than for potassium hydroxide, for sodium hydroxide than

3 Hydrocyanic acid boils at $+25.7^{\circ} \mathrm{C}$. and freezes at $-14.9^{\circ} \mathrm{C}$. The specific gravity of the liquid is 0.72 at $0^{\circ} \mathrm{C}$. 
for sodium cyanide, and for methyl alcohol than for ethyl alcohol. Useful measures include the use of low concentrations of alkali, stirring when the hydrocyanic acid is added and the removal of the precipitated cyanide as promptly as possible.

Data on the purity of synthetic potassium cyanide as determined by several methods are reported in Table 4 and similar data for sodium cyanide in Table 5.

TABLE 4.-Determination of purity of potassium cyanide with weight burettes

[The sample used throughout was synthesized from liquid HCN and KOH in absolute ethyl alcohol solu-

tion. It contained a negligible amount of sodium, amounting to 0.32 per cent, calculated as $\mathrm{NaCN]}$

\begin{tabular}{|c|c|c|c|c|c|c|}
\hline 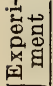 & $\begin{array}{l}\text { Method of an- } \\
\text { alysis }\end{array}$ & $\begin{array}{l}\text { Standard solution made } \\
\text { from- }\end{array}$ & $\begin{array}{l}\text { Analy- } \\
\text { sis A }\end{array}$ & $\begin{array}{l}\text { Analy- } \\
\text { sis B }\end{array}$ & $\begin{array}{l}\text { Analy- } \\
\text { sis av- } \\
\text { erage }\end{array}$ & Remarks \\
\hline 1 & $\begin{array}{l}\text { Liebig with } \\
\text { no addition. }\end{array}$ & Weighed $\mathrm{AgNO}_{3}$ crystals & $\mid \begin{array}{c}\text { Per cent } \\
99.67\end{array}$ & $\begin{array}{l}\text { Per cent } \\
99.57\end{array}$ & $\begin{array}{c}\text { Per cent } \\
99.62\end{array}$ & $\begin{array}{l}\text { Sample desiccator dried. Con- }-{ }^{2}-{ }_{2} \\
\text { tained trace of } \mathrm{K}_{2} \mathrm{CO}_{3} \text { by } \\
\mathrm{BaCl}_{2} \text { test. Analysis done } 9 \\
\text { weeks after preparation of } \\
\text { sample. }\end{array}$ \\
\hline 2 & $\begin{array}{l}\text { Liebig with } \\
\text { KI-NaOH. }\end{array}$ & -....do... & 99.85 & 99.80 & 99.83 & $\begin{array}{l}\text { Analysis done at same time as } \\
\text { (1)1. Shows slightly higher } \\
\text { and undoubtedly more accu- } \\
\text { rate result because of use of } \\
\text { KI-NaOH. }\end{array}$ \\
\hline 3 & & -.....do- & 99. 73 & 99. 76 & 99.75 & $\begin{array}{l}\text { Similar to above, except done } \\
10 \text { weeks later. Difference } \\
\text { probably due to change in } \\
\text { sample, or in silver solution. }\end{array}$ \\
\hline 4 & & Weighed Ag shot.-.- & 99.86 & 99.84 & 99.85 & $\begin{array}{l}\text { Sample desiccator dried. An- } \\
\text { alysis done at same time as } \\
\text { (3). }\end{array}$ \\
\hline 5 & Do. & do & 99. 78 & 99.70 & 99.74 & $\begin{array}{l}\text { Similar to above, except sample } \\
\text { was both desiccator dried and } \\
\text { dried at } 110^{\circ} \mathrm{C} \text {. Shows net } \\
\text { loss in purity by latter drying. }\end{array}$ \\
\hline 6 & Lundell_ & $\mathrm{NiSO}_{4} \cdot\left(\mathrm{NH}_{4}\right)_{2} \mathrm{SO}_{4} \cdot 6 \mathrm{H}_{2} \mathrm{O}_{-}$ & 99.23 & & & Nickel solution was standard- \\
\hline 6 & Do. & do & 99.29 & 99.44 & 99.32 & $\begin{array}{l}\text { ple desiccator dried. These } \\
\text { analyses done } 9 \text { weeks after }\end{array}$ \\
\hline 7 & Do. & -...do_. & 99.47 & 99.56 & 99.52 & $\begin{array}{l}\text { Sample dried both in desiccator } \\
\text { and at } 110^{\circ} \mathrm{C} \text {. Analysis done } \\
\text { at the same time as (6). Dif- De } \\
\text { ference not due to moisture } \\
\text { content (about } 0.03 \text { per cent). }\end{array}$ \\
\hline
\end{tabular}

1 Figures here and in tables refer to the experiment number.

TABLE 5.-Determination of purity of sodium cyanide with weight burcttes

[The sample used in experiments 1-4 was synthesized from liquid $\mathrm{HCN}$ and $\mathrm{NaOH}$ in absolute ethyl alcohol solution. The sample used in experiment 5 was synthesized from liquid $\mathrm{HCN}$ and $\mathrm{C}_{2} \mathrm{H}_{6} \mathrm{ONa}$ in absolute ethyl alcohol solution]

\begin{tabular}{|c|c|c|c|c|c|}
\hline $\begin{array}{l}\text { Ex- } \\
\text { peri- } \\
\text { ment }\end{array}$ & $\begin{array}{l}\text { Method of } \\
\text { analysis }\end{array}$ & $\begin{array}{c}\text { Analy- } \\
\text { sis A }\end{array}$ & $\begin{array}{l}\text { Analy- } \\
\text { sis B }\end{array}$ & \begin{tabular}{|} 
Analy- \\
sis \\
aver- \\
age
\end{tabular} & Remarks \\
\hline 1 & $\begin{array}{l}\text { Liebig with no } \\
\text { addition. }\end{array}$ & $\mid \begin{array}{c}\text { Per cent } \\
98.38\end{array}$ & $\begin{array}{c}\text { Per cent } \\
98.52\end{array}$ & $\begin{array}{c}\text { Per cent } \\
98.45\end{array}$ & $\begin{array}{l}\text { Sample desiccator dried. Contained about } 0.8 \text { per cent } \\
\mathrm{Na}_{2} \mathrm{CO}_{3} \text {, by } \mathrm{BaCl}_{2} \text {. Analysis done } 8 \text { weeks after prep- } \\
\text { aration of sample. Silver solution for this experi- } \\
\text { ment and also for experiments } 2 \text { and } 3 \text { was prepared } \\
\text { from weighed } \mathrm{AgNO}_{3} \text { crystals. }\end{array}$ \\
\hline 2 & $\begin{array}{l}\text { Liebig with } \\
\text { KI-NaOH. }\end{array}$ & 98.71 & 98.52 & 98.62 & $\begin{array}{l}\text { Similar to a bove. Shows slightly higher and undoubt- } \\
\text { edly more accurate result because of use of KI-NaOH. } \\
\text { Done at same time as (1). }\end{array}$ \\
\hline 3 & -....do_. & 98.89 & 98.70 & 98.80 & $\begin{array}{l}\text { Sample after drying in desiccator was fused in a nickel } \\
\text { crucible under hydrogen. Shows only a slight gain } \\
\text { in purity by fusion. Done soon after (1). }\end{array}$ \\
\hline 4 & Lundell_....... & 98.24 & 98.22 & 98.23 & $\begin{array}{l}\text { Sample dried in desiccator and then at } 110^{\circ} \mathrm{C} \text {. Analy- } \\
\text { sis done } 6 \text { weeks after (1). Nickel solution was pre- } \\
\text { pared from nickel-ammonium sulphate and stand- } \\
\text { ardized by electro-analysis. }\end{array}$ \\
\hline 5 & $\begin{array}{l}\text { Liebig with } \\
\text { KI-NaOH. }\end{array}$ & 99.16 & 99.10 & 99.13 & $\begin{array}{l}\text { Sample dried in desiccator. Analysis done one week } \\
\text { after preparation of sample. Contained less than } 0.1 \\
\text { per cent } \mathrm{Na}_{2} \mathrm{CO}_{3} \text {, by } \mathrm{BaCl}_{2} \text {. Drying at } 125^{\circ} \mathrm{C} \text {. did } \\
\text { not increase purity. }\end{array}$ \\
\hline
\end{tabular}




\section{DISCUSSION OF RESULTS}

The synthetic potassium cyanide was considerably purer than the synthetic sodium cyanide, even after repeated attempts to improve the latter. This may be partly explained by the relatively high solubility of potassium carbonate in alcohol ('Table 2), which tends to prevent contamination by this impurity. The sodium cyanide preparations usually contained an appreciable amount of carbonate, except the sample made by Strachan's procedure ('Table 5, No. 5). In that experiment, the alcoholic solution was somewhat easier to filter and the Ziegler apparatus for generating hydrocyanic acid was supplied with a solution that had been freed from carbonate by treatment with barium hydroxide. This sample, however, still contained an appreciable amount of coloring matter. Further experience with Strachan's procedure would no doubt lead to better results.

The solubilities listed in Table 2 apply to separate salts, and in the case of mixtures may be altered by mutual solubility effects. No marked effects of this nature, however, were observed in the experiments.

The analyses of cyanide show slightly lower results by the Lundell than by the Liebig method (Tables 4 and 5), a difference similar to that reported by Lundell (16). In an attempt to explain this diffence, the recrystallized nickel ammonium sulphate used was examined for cobalt. About 0.04 per cent of cobalt was found present (ratio of nickel to cobalt of about $400: 1$ ), and the low result for cyanide must have been partly due to this impurity. The complete elimination of cobalt is therefore important if maximum accuracy is to be secured. At best, the conditions of the titration probably affect the end point to a greater extent than in the Liebig method, where it is also easier to obtain a pure salt for preparing the standard solution. The reaction taking place during the titration of cyanide with nickel solution is quite definite, however, as shown by the recent solubility determinations of Corbet (31).

The analytical results by the Liebig titration with silver nitrate (Tables 3, 4, and 5) make it evident that those of Frary and Porter (17) by this method must have been approximately correct and not about 3 per cent low, as they thought. None of their data on the silver solutions used for measuring electrode potentials need to be changed, as they employed the Liebig titration values.

\section{CONCLUSIONS}

1. The high accuracy of the modified Liebig method for titrating alkali cyanide with silver nitrate solution and iodide indicator is supported by: (a) The weight of the evidence from the literature; (b) the additional results obtained in this investigation, through the preparation of potassium cyanide of high purity. The error of the Liebig method, under best conditions, is probably less than 0.2 per cent and may even be less than 0.1 per cent.

2. It is more difficult to synthesize pure sodium cyanide than pure potassium cyanide, by adding liquid hydrocyanic acid to an ethyl alcohol solution of the hydroxide.

3. An alcoholic solution of sodium ethoxide has advantages over one of sodium hydroxide, for the synthesis of pure sodium cyanide, especially in eliminating carbonate as an impurity. 
4. The Ziegler apparatus for generating hydrocyanic acid can be operated so as to eliminate carbon dioxide, while this is difficult to effect with the Wade and Panting apparatus.

5. More investigation is needed on the laboratory synthesis of pure alkali cyanide and especially of sodium cyanide. The favorable conditions should be defined more exactly and the technique better standardized. The elimination of organic impurities derived from condensation products (of either aldehyde or hydrocyanic acid) is particularly important.

6. Alkali cyanides and related salts are more soluble in methyl than in ethyl alcohol. For certain grades of cyanide, methyl alcohol is more suitable as a solvent for purification by recrystallization. For other grades, ethyl alcohol is more satisfactory. Recrystallization is at best, however, a slower and less efficient process than synthesis with liquid hydrocyanic acid.

7. It is recommended that, in future work on this subject, the silver nitrate titration with weight burettes be adopted as one method of analysis for determining and reporting the purity of alkali cyanide, in order to facilitate the comparison of results.

\section{ACKNOWLEDGMENTS}

Acknowledgments are due to the following firms and persons: American Cyanamid Co., and Roessler \& Hasslacher Chemical Co., both of New York, N. Y., for contributing samples of cyanides and information on analytical methods; W. Blum, who directed this investigation and made many helpful suggestions; and N. Bekkedahl, H. B. Knowles, and R. M. Wick, for assistance in the preparation or analysis of the cyanide samples.

\section{BIBLIOGRAPHY}

1. F. Rogers and E. Rogers, On Certain Metallic Cyanurets (Cyanides), Phil. Mag. [3], 4, p. 91; 1834.

2. A. Wiggers, A Convenient Method for Preparing Potassium Cyanide, Ann. Pharm., 29, p. 65; 1839 .

3. C. F. O. Glassford and J. Napier, On the Cyanides of the Metals and Their Combinations with Cyanide of Potassium, Pt. 2, Cyanide of Silver, Phil. Mag. [3], 25, p. 66; 1844 .

4. J. Liebig, Process for Determining the Amount of Hydrocyanic Acid in Medicinal Prussic Acid, Bitter Almond Water and Laurel Water, Ann. Chem. Pharm., y\%, p. 102;1851; Q. J. Chem. Soc., 4, p. 219; 1852.

5. M. J. Fordos and A. Gélis, The Analysis of Commercial Potassium Cyanide, J. pharm. chim. [3], 23, p. 48; 1853 .

6. J. Eneu Loughlin, Preparation and Testing of Cyanide of Potassium, American Chemist, 5 , p. $396 ; 1875$.

7. J. B. Hannay, A New Process for the Volumetric Estimation of Cyanides, J. Chem. Soc., 33, p. 245; 1878.

8. A. Joannis, Compounds of Cyanogen with Metals, Ann. chim. phys. [5], 26, p. $482 ; 1882$.

9. C. A. Lobry de Bruyn, Methyl and Ethyl Alcohol as Solvents, Z. physik. Chem., 10, p. 782; 1892; A. Seidell, Solubilities, 2d ed., p. 531, D. Van Nostrand Co., New York; 1919.

10. G. Denigès, General Method for the Volumetric Determination of Silver in Any Form, Compt. rend., 11\%, p. 1078; 1893. On a New Cyanometric Method and Its Applications, Ann. chim. phys. [7], 6, p. 381; 1895.

11. W. J. Sharwood, Notes on the Estimation of Cyanogen by Silver Nitrate, Using Potassium Iodide and Ammonia as Indicators, J. Am. Chem. Soc., 19, p. $400 ; 1897$. 
12. J. Wade and L. C. Panting, Preparation of Dry Hydrogen Cyanide and Carbon Monoxide, J. Chem. Soc., Trans., 73, p. 255; 1898.

13. J. E. Clennell, The Chemistry of Cyanide Solutions, 2d ed., McGraw-Hill Book Co., New York; 1910.

14. G. H. Clevenger and M. L. Hall, The Electrolysis of Aqueous Solutions of the Simple Alkaline Cyanides, Trans. Am. Electrochem. Sur., 24, p. 271;

15. J. T. Burt-Gerrans and G. O. Morrison, Determination of Free Cyanide in Cyanide Copper and Brass Baths, Paper No. 101 from the Chemical Laboratories, University of Toronto; 1914.

16. G. E. F. Lundell, A New Method for the Determination of Free Cyanide in Electroplating Solutions, Trans. Am. Electrochem. Soc., 25, p. 369; 1914; G. E. F. Lundell and J. A. Bridgman, A New Method for the Determination of Hydrocyanic Acid and the Alkali Cyanides, J. Ind. Eng. Chem., 6, p. $554 ; 1914$.

17. F. C. Frary and R. E. Porter, Single Potentials in the Silver Cyanide Plating Bath, as Affected by Its Composition and Concentration, Trans. Am. Electrochem. Soc., 28, p. 207; 1915. 18. D. B. Dott, Determination of Hydrocyanic Acid, Pharm. J., 96, p. 368;

19. J. E. Bucher, The Fixation of Nitrogen, J. Ind. Eng. Chem., 9, p. 233; 1917. See pp. 237, 246.

20. H. A. Pelton and M. W. Schwarz, The Manufacture of Hydrocyanic Acid, Chem. Met. Eng., 20, p. 165; 1919.

21. D. H. Cocheret, Tables Annuelles de Constantes et Données Numériques, 2, p. 460; 1911. A. Seidell. Solubilities, 2 d ed., p. 635 . D. Van Nostrand Co., New York; 1919.

22. R. Leitch Morris, The Determination of Hydrocyanic Acid, Pharm. J., London, [4], 51, or 105, p. 83; 1920. Also, Chemist Druggist, 93, p. 1040; 1920.

23. G. Harker, The Acid and Alkaline Decomposition of Potassium Cyanide, with A Note on the Determination of Formic Acid in the Presence of Hydrocyanic Acid, J. Soc. Chem. Ind., 40, p. 182-T; 1921.

24. K. Ziegler, On the Preparation of Anhydrous Hydrocyanic Acid, Ber., 54, p. $110 ; 1921$. Hydrogen Cyanide (Anhydrous), Organic Syntheses, \%, p. 50. J. Wiley \& Sons, New York; 1927.

25. C. K. Ingold, The Form of the Vapor Pressure Curve at High Temperatures. Pt. 2. The Curve for Sodium Cyanide, J. Chem. Soc., 123, p. 885; 1923.

26. H. Bassett and A. S. Corbet, A Phase Rule Study of the Cupro-, Argento-, Auro-, and Thallo-cyanides of Potassium, J. Chem. Soc., 125, p. 1660; 1924.

27. Methods of Analysis, Assoc. Official Agr. Chem., Washington, D. C., $2 \mathrm{~d}$ ed., p. 353; 1925.

28. Organic Syntheses, 4, pp. 11, 29; 1925; 6, pp. 40, 48; 1926; 8, p. 30; 1928. John Wiley \& Sons; New York.

29. E. W. Guernsey and M. S. Sherman, The Thermal Dissociation of Sodium Cyanide, J. Am. Chem. Soc., 48, p. 695; 1926.

30. L. Hackspill and R. Grandadam, Contribution to the Study of Some Potassium and Sodium Salts, Ann. chim. [10], 5, p. 218; 1926.

31. A. S. Corbet, A Phase-rule Study of the Zinci-, Cadmi-, Mercuri-, and NickeloCyanides of Potassium, J. Chem. Soc., p. 3190; 1926.

32. J. A. Cranston and A. Y. Livingstone, A Comparison of Some of the Physical Properties of the Alkali Cyanates and Azides, J. Chem. Soc., p. 501, 1926; A. Seidell. Solubilities, 2d ed., Supplement, pp. 1364, 1424, D. Van Nostrand Co., New York; 1928.

33. E. B. Sanigar, The Titration of Potassium Cyanide, and of Free Cyanide in Silver Plating Solutions, by Means of Silver Nitrate, Trans. Am. Electrochem. Soc., 58, p. 435; 1930.

Washington, April 16, 1931.

$55946^{\circ}-31-10$ 